\title{
PROJECT DEVELOPMENT EVALUATION TOWARDS CONSTRUCTION WASTE MANAGEMENT GREEN BUILDING CONCEPT ORIENTED
}

\author{
Muhammad Rudiansyah \\ Civil Engineering \\ Narotama University, Surabaya \\ mrudiansyah38@gmail.com \\ F Edy Rooslan Santoso \\ Civil Engineering \\ Narotama University, Surabaya \\ rooslan.edy@gmail.com \\ Ronny Durrotun Nasihien \\ Civil Engineering \\ Narotama University, Surabaya \\ ronny.durrotun@narotama.ac.id
}

\begin{abstract}
Surabaya as one of the metropolitan cities in Indonesia, has a high level of project development and an attraction for the community. This is predicted to provide potential changes in environmental quality such as decreased road performance, wastewater and increased volume of waste generation, increased noise and the emergence of community perceptions and concerns about the planned activity. The construction of construction projects will always produce a considerable amount of waste, so that if management is not carried out, the construction waste can become a serious problem for the environment. The waste management model is basically carried out through the stages of avoid, reduce, recycle, and dispoal. This study aims to determine the material that has the greatest potential to produce construction waste. The method used in this study is first to use the Pareto method, the first step that must be done is to rank using Trading Consumable Materials (TCM) based on the total price so that a large price is obtained into the first order, then using the Pareto method to determine the material to be investigated in determining the most construction waste. Furthermore, the second one uses the waste level calculation to determine the waste volume from the results of the Pareto analysis that has been obtained. Furthermore, the third is the calculation of the waste index to determine the volume of residual construction waste in the project in $\mathrm{m} 2$ in each day, and the last is the calculation of waste cost to determine whether a large waste volume will produce a large waste as well.
\end{abstract}

Keywords: Construction waste, Pareto Method, green bulding concept

\section{INTRODUCTION}

This research is very necessary for project development because every development has a great influence on the environment and the project itself. Especially in the case of construction waste management towards project development, several efforts must be made so that construction waste can be managed as much as possible. As for the result of the generation of construction waste a project development can be minimized as little as possible. The study was conducted in the hope of providing solutions to problems related to construction waste management in an agency in the implementation of construction projects.

Based on problem background, it can be proposed problem formulation as: 
1. How to identify the sources and factors causing construction waste in the project implemented

2. How to minimize construction waste generation in the projects implemented?

The purpose of this study are:

1. Knowing the causes of sources and factors of construction waste management in project development

2. Know how to minimize construction waste generation in the waste management system in accordance with the provisions of the analysis

\section{THEORITICAL REVIEW}

\section{Previous Research}

The following are several studies related to the evaluation of project development on the management of waste-oriented green building concept construction:

1. Primadita Yuliani, Waste Management for Structural Work in Construction Projects in the Special Region of Yogyakarta.

2. Pramesti Andiani, Identification of Construction Waste Composition in High-Rise Building Structures.

3. Maria Dwi Ferdiana, Study of the remaining Material in the Building and Housing Project.

4. Sri Puji Hastuti, Chundakus Habsya, and Thaufiq Lilo Adi Sucipto, Waste Management in Building Construction Projects as Part of Green Construction Realization Efforts.

5. Rudi Dwi Asguna, Evaluation of Time Construction Material with Waste Management Model.

\section{Construction Waste}

1. Definition of Construction Waste

Construction waste is defined as material that is not used that results from the process of construction, repair or change or any goods produced from the process or an accident that can not be directly used at that place without any further treatment.

2. Cause of Construction Waste

Construction waste has several causes for the occurrence of construction waste in a construction project is (Rubina Greenwood, 2004):
a. Excessive consumption of resources
b. Material damage due to mishandling or shipping
c. Damage to the material due to weather and improper storage.
d. Vandalism
e. Rework/Improve
f. Lack of data collection on sent and used material
g. Material from the preparation and finishing work
h. Waste from project office operations

3. Impact of Construction Waste

Construction waste as well as other wastes, especially solid waste, have an impact on existing environmental conditions. (Ramachandran, 1990) categorizes these impacts, as follows:

a. Deterioration of natural resources

b. Construction of buildings in residential areas causes noise pollution

c. Polusi Pollution of chemicals caused by particles released into the air due to the production and transportation of materials 
4. Hirearki Construction Waste Management

Hirearki's management of construction waste based on Chun Peng, Domenic E. Scorpio and Charles Kibert (1995) are:

a. Reduction, is the best and efficient way to minimize the waste produced.

b. Reuse, is the transfer of the use of an item for use to another

c. Recycling, is a process of recycling old material into new material but it is also economically profitable.

d. Landfilling, is the final choice that can be made in waste management, namely the disposal of waste to the final shelter.

\section{Green Building Concept}

The definition of green building is a building where since it began in the planning, construction and operation stages of maintenance taking into account aspects of protecting, conserving, reducing the use of natural resources, maintaining the quality of indoor air quality and paying attention to the health of its inhabitants. The purpose and purpose of green building (green building) is designed to reduce the impact of the built environment on human and natural health. The Building Environmental Management (BEM) aspect is an important assessment in green building certification. If the method of applying aspects of Building Evironment Management can be applied appropriately, the construction waste generated in the green building construction process can be clearly seen the causes and ways to overcome them so that in the future the BEM aspect can be used as an important element in construction projects in Indonesia, especially green buiding. Material Resources and Cycle is one of the assessment in Green Building, this assessment is part of a passive design in building environmentally friendly buildings. Material cycle in a project is very influential in aspects of Green Building so that material management is very necessary in accordance with the provisions of Material Resources and Cycle.him.

\section{RESEARCH METHODOLOGY}

\section{Types of Work}

1. Pile Cap Work

Pile cap is a structural element that is above the pile foundation so that it functions to spread the load from the column to the piles. Pile cap work can be done after the pile work is finished and the pile cap work floor is finished.

2. Tie Beam Floor Plate Work

Tie beam is a beam that connects the pile cap to one another so that the pile becomes stronger and stiffer. The function of a tie beam is to level the forces on a building, as a barrier beam for the reaction force of the soil, and as an increase in the stiffness between the pile cap.

3. Column Cuttings and Retaining Wall Work

The column is the main structure of the construction of a portal made of reinforced concrete that serves to withstand the weight of gravity on each floor, including lateral loads due to earthquakes and wind which is transmitted to the column and then to the foundation. Retaining wall is a reinforced concrete wall construction which is casted around a building that serves as a barrier to the soil so that its condition remains stable and cannot erupt or protect against erosion. 


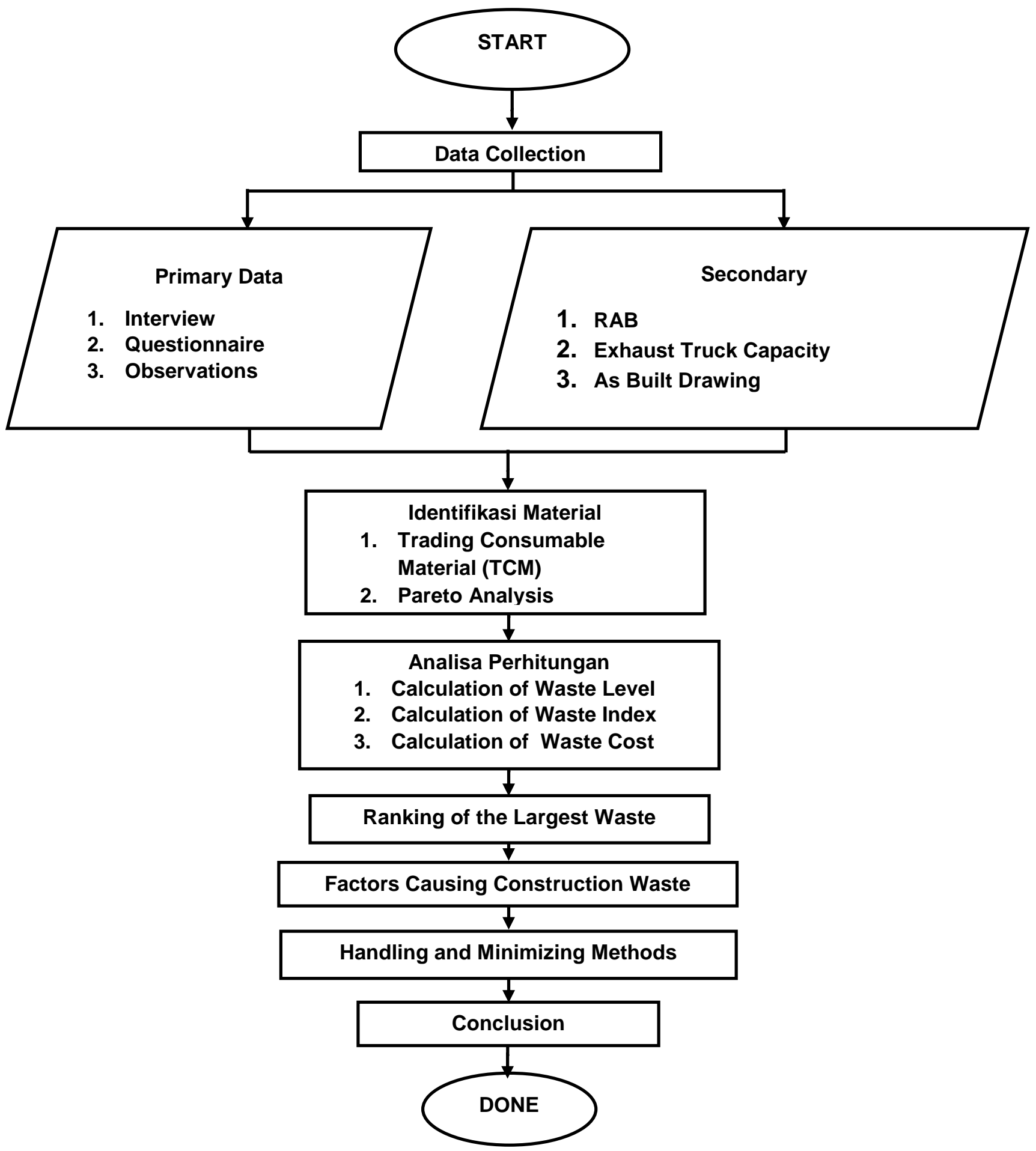

Figure 1. Research Flowchart

\section{RESULTS AND DISCUSSION}

\section{Data Analysis}

1. Populasi Research Population and Samples

The population used in this study is construction staff workers on related projects, where the total construction workers on related projects totaled 150 people with each different position according to the existing organizational structure. 
The sample was chosen based on the position which is very influential in this study, so there are some workers who are chosen according to the influence of this research.

The sample calculation uses the Slovin formula below:

Slovin formula:

$$
\begin{aligned}
& n=\frac{N}{N . d 2+1} \\
& n=\frac{150}{150.10 \%+1}=9.375
\end{aligned}
$$

From the calculation above, where the population of construction staff is 150 people. then it will produce a sample of respondents 9 people according to the calculations above. In sampling using accidental sampling that is sampling by means of considerations which respondents can produce accurate data in this study. In the selection of 9 respondents selected based on the position that is very influential in this study, this is in order to get results that are actually in the field to be used as research. The positions that fill in the questionnaire and are considered influential in this study are as follows:

Table 1. Position of Respondents

\begin{tabular}{|c|l|}
\hline No & \multicolumn{1}{|c|}{ Position } \\
\hline 1 & Ass Safety \& G.A \\
\hline 2 & HSE Officer \\
\hline 3 & QHSE / SQHSEM \\
\hline 4 & K3 \\
\hline 5 & Construction \\
\hline 6 & Quality Control staff \\
\hline 7 & Quality Surveyor \\
\hline 8 & Supervisor \\
\hline 9 & Engineer \\
\hline
\end{tabular}

Based on the characteristics of the respondents above, it is found that respondents who are considered influential in this study, the respondents mentioned above will be interviewed online and one offline because according to company policies related to the co-19 pandemic.

2. Trading Consumable Material (TCM) Analysis

In identifying material, the first step that must be taken is to rank material using the Trading Consumable Material (TCM) method with a reference based on the total price, so that material with high prices will be ranked first. Furthermore, the percent cost column is made, then it is cumulative to produce the percent cost column that has been obtained.

The way to determine the percent of cost is the total price per material divided by the price of all materials and then it can be multiplied by $100 \%$. The percent cost column is made in tabular form and contains various materials and the volume and price of the material itself as follows: 
Table 2. Trading Consumable Material (TCM) Analysis

\begin{tabular}{|c|l|c|c|c|c|c|c|c|}
\hline No & Material & Sat & Volume & HSPK & Total Price & $\begin{array}{c}\text { Comulative } \\
\text { Price }\end{array}$ & $\begin{array}{c}\% \\
\text { Price }\end{array}$ & $\begin{array}{c}\text { Kom } \\
\% \\
\text { Cost }\end{array}$ \\
\hline 1 & Iron & $\mathrm{kg}$ & $154,543.00$ & 10,910 & $1,686,064,130$ & $1,686,064,130$ & 53.34 & 53.34 \\
\hline 2 & $\begin{array}{l}\text { Concrete } \\
\text { Readmix }\end{array}$ & $\mathrm{m} 3$ & 581.35 & 971,689 & $564,891,400$ & $2,250,955,530$ & 17.87 & 71.21 \\
\hline 3 & Multiplex & $\mathrm{m} 2$ & $4,258.60$ & 191,320 & $814,755,352$ & $3,065,710,882$ & 25.78 & 96.99 \\
\hline 4 & $\begin{array}{l}\text { Concrete } \\
\text { Brick }\end{array}$ & $\mathrm{m} 2$ & 735.28 & 126,670 & $93,137,917$ & $3,158,848,799$ & 2.95 & 99.93 \\
\hline 5 & $\begin{array}{l}\text { Steel } \\
\text { Plate }\end{array}$ & $\mathrm{m} 2$ & 92.70 & 22,294 & $2,066,653$ & $3,160,915,453$ & 0.07 & 100 \\
\hline
\end{tabular}

3. Pareto Analysis

The results of the calculation of the remaining material costs that have been obtained from the calculation of Trading Consumable Materials (TCM) based on total assets are sorted from the largest remaining value to the smallest material.

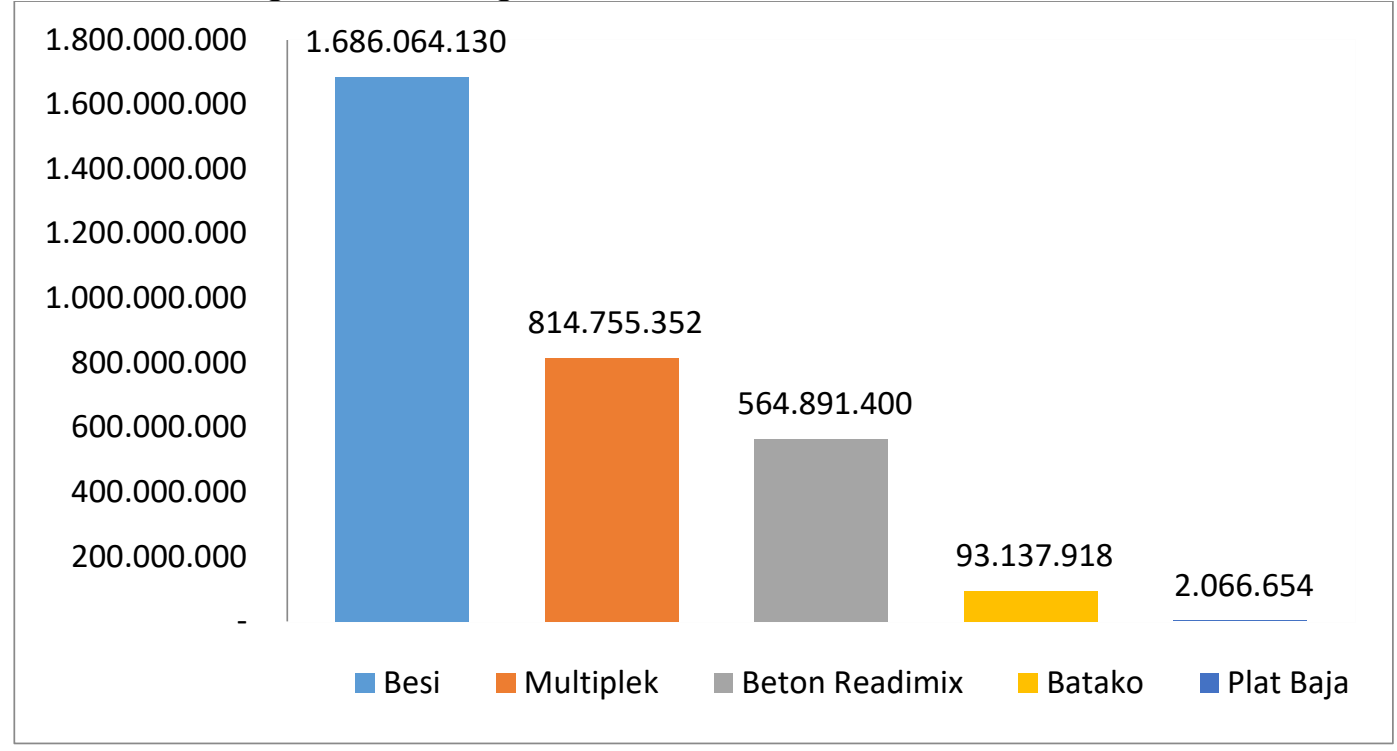

Picture 4.2 Pareto Diagram Image

The remaining material selected for research is $20 \%$ of the total material or material which mostly produces construction waste. The remaining dominant construction material in the Surabaya one galaxy apartment development project is taken from the value of the largest remaining material cost, namely metrial iron which has a cost of $\mathrm{Rp}$. $1,686,064,130$.

4. Waste Analysis

a. Waste :Level

Waste level calculation to determine the volume of waste from the amount of material that has been obtained from the results of the Pareto analysis. How to determine the volume of waste is by means of the volume of logistical arrival or incoming material is reduced by the material that has been installed, while to determine the waste results, namely the volume of waste divided by the arrival of logistics or material brought in, then the result is multiplied by 100 . In this calculation, we can find out material that has the potential to cause high to low volume waste. 
Table. 3. Waste Level Recapitulation

\begin{tabular}{|c|l|c|c|c|c|c|}
\hline No & \multicolumn{1}{|c|}{ Material } & Sat & $\begin{array}{c}\text { Arrival of } \\
\text { Logistics }\end{array}$ & Installed & $\begin{array}{c}\text { Waste } \\
\text { Volume }\end{array}$ & $\begin{array}{c}\text { Waste Level } \\
(\%)\end{array}$ \\
\hline 1 & Iron & $\mathrm{kg}$ & $162,270.15$ & $154,543.00$ & $7,727.15$ & 4.76 \\
\hline 2 & Concrete Readmix & $\mathrm{m} 3$ & 598.79 & 581.35 & 17.44 & 2.91 \\
\hline 3 & Multiplex & $\mathrm{m} 2$ & $4,386.36$ & $4,258.60$ & 127.76 & 2.91 \\
\hline 4 & Concrete Brick & $\mathrm{m} 2$ & 757.34 & 735.28 & 22.06 & 2.91 \\
\hline 5 & Steel Plate & $\mathrm{m} 2$ & 97.34 & 92.70 & 4.64 & 4.76 \\
\hline
\end{tabular}

In the table above there is material that produces the largest percentage of waste level is Iron material with a waste volume of $162,270.15 \mathrm{~kg}$ and has a waste level of $4.76 \%$. while the material that has the smallest level of waste level is steel plate material that produces waste volume of $97.34 \mathrm{~m} 2$ and has a level of waste level of $4.76 \%$.

b. Waste Index

Waste index can be obtained from interviews with several respondents in the field. To find out the value of $\mathrm{W}$ that is from the size or volume of the waste disposal truck every day, then multiplied by the number of times in a day the disposal of waste by truck is done, while the value of the GFA is from the area of the building on the project. From the data obtained it is known that the construction project of apartment one east if disposing of the construction material waste produced by the project uses trucks if the volume of waste is too much and the storage space is almost no empty space available. So from the above information, the calculation is as follows:

$$
\begin{aligned}
& \text { Waste Index }=\frac{W}{G F A} \\
& \text { Waste Index }=\frac{4 m 3 x(1 \times 8)}{2016 m 2} \\
& \text { Waste Index }=\frac{32}{2016}=0.0158
\end{aligned}
$$

The result of the waste index is 0.0158 , the value generated according to the calculation can be interpreted that in $\mathrm{m} 2$ there is a residual material of 0.0158 , but the figure cannot be concluded whether the waste management in the project is good or not so as to state a good waste index limit or not, further research must be done by making a waste cost calculation in order to find out the amount of the value of the waste cost.

c. Waste Cost

The result of the waste index is 0.0158 , the value generated according to the calculation can be interpreted that in $\mathrm{m} 2$ there is a residual material of 0.0158 , but the figure cannot be concluded whether the waste management in the project is good or not so as to state a good waste index limit or not, further research must be done by making a waste cost calculation in order to find out the amount of the value of the waste cost. 
Table 4. Waste Cost Recapitulation

\begin{tabular}{|c|c|c|c|c|c|c|c|c|c|}
\hline No & Material & $\begin{array}{c}\text { Vol. } \\
\text { Installed } \\
\text { Material }\end{array}$ & $\begin{array}{c}\text { Vol. Material } \\
\text { Used }\end{array}$ & $\begin{array}{c}\text { Vol. } \\
\text { Waste }\end{array}$ & $\begin{array}{c}\text { Waste } \\
\text { Level }\end{array}$ & Unit Price & Total Price & $\begin{array}{l}\text { Job } \\
\text { Load }\end{array}$ & Waste Cost \\
\hline 1 & Iron & $154,543.00$ & $162,270.15$ & $7,727.15$ & 4.76 & 10,910 & $1,770,367,336$ & 0.53 & $84,303,206$ \\
\hline 2 & $\begin{array}{l}\text { Concrete } \\
\text { Readmix }\end{array}$ & 581.35 & 598.79 & 17.44 & 2.91 & 971,689 & $581,838,142$ & 0.18 & $16,946,742$ \\
\hline 4 & $\begin{array}{l}\text { Concrete } \\
\text { Brick }\end{array}$ & 735.28 & 757.34 & 22.06 & 2.91 & 126,670 & $95,932,055$ & 0.03 & $2,794,137$ \\
\hline 5 & Steel Plate & 92.70 & 97.34 & 4.64 & 4.76 & $22,294.00$ & $2,169,986$ & 0.00 & 103,332 \\
\hline
\end{tabular}

Source: Data Analysis Results

The results of table 4.5 above can be seen that the material that has the greatest value of waste cost is concrete steel with the value of waste cost generated at Rp. $84,303,206$. While the value that shows the ranking of the largest percentage of waste level is concrete steel material with the value generated by the waste level of $4.76 \%$.

Therefore, it can be proven that material with a large percentage of waste level will have a large waste cost according to the results of the largest volume of remaining material. In addition, the weight of the work also affects the determination of the value of waste cost. So it can be concluded that if the material has a work weight and produces a large waste level, the value of waste cost will automatically be large as well, the value of time will follow the work weight and waste level.

In order to be able to suppress excessive residual material on iron material that has a very high residual material value, this is done in a way that is the accuracy of the material calculation of the project implemented, so that field people can pay more attention to the calculation form and as often as possible to monitor the material.

5. Calculation of Waste Volume

The calculation of the amount of construction solid waste assuming $0.5 \mathrm{~L} /$ person / day, with the following calculation:

Amount of construction solid waste generation:

$=0.5 \mathrm{~L} /$ person $/$ day $\times 150$ people

$=75 \mathrm{~L} /$ person $/$ day

From the results of the above calculation the emergence of construction solid waste is 75 $\mathrm{L} /$ person / day. These results are not accurate just as an assumption to find out construction waste.

\section{Factors Causing and How to Tackle Construction Waste}

Here are some of the factors causing construction waste in one of the jobs that cause the most material waste along with solutions to minimize and utilize the remaining material that has already happened in several jobs:

1. Work in the field that most often causes construction waste or material residue, which is formwork work because for the material used in formwork work will become construction waste if it is not managed as much as possible, iron cutting work is also one of the causes of construction waste and therefore work These must be monitored as much as possible and in ready mix concrete work because for the casting work itself, it must produce concrete that is scattered when ready mix concrete works.

2. Some causes of the remaining material are:

a. Structural work greatly influences the waste produced, ie pieces of iron that cannot be used anymore, the installation of cuttings must also be considered the level of elevation of the previous floor to the floor you want to work on. 
b. Iron material that is not used due to design changes and results in the remaining iron cutting not in accordance with the work plan produces the highest percentage of construction waste before formwork work, in an effort to minimize the occurrence of construction waste that occurs must be monitored as much as possible and so that no changes occur design in order not to throw away the iron that has already been cut.

c. Where the project from the previous planning has been calculated about the material requirements and specifications have been written before, but there are changes in design or specifications by the owner's request to make specifications and calculations not in accordance with the plan, then do the conversion play, then the material that has already gone ahead so that it can be change it to the supplier so that the material will not be wasted and that is already available and cannot be exchanged, the material is used for other work or offered to other projects that require the same material.

d. Formwork also accounts for the highest percentage of waste after pembesian work. Because the formwork itself after the work is finished plywood or wood can not be used anymore. The material solution is collected and the rest is sold again to the collectors.

3. How to minimize the causes of construction waste, namely:

a. There is periodic monitoring when work is running or periodic monitoring so that there is no residual material.

b. Utilizing the remaining iron if there are pieces of iron whose dimensions can still be used for other work.

c. Strive to prevent changes in specifications and requirements for materials and images in the field.

d. Arrange and tidy up the place for the remaining material in accordance with the dimensions and type of construction waste.

e. Re-check the material requirements before being imported so that no volume error occurs.

4. Solutions to utilize the remaining material that has already occurred in construction work, namely:

a. Return of material to the supplier if it has been purchased and there is a change in specifications or drawings on the field.

b. Reuse for materials that can still be used again in good condition and still suitable for use

c. The remaining material produced will be offered in advance to other projects that need it before it is sold to collectors so it can be used again according to its function.

\section{CONCLUSION}

Based on the results of research and discussion conducted by researchers regarding the evaluation of project development towards waste management oriented green building concept construction at One Galaxy Apartment Surabaya, the following conclusions can be obtained:

1. The source of the cause of construction waste is mainly the change in the volume listed which is not in accordance with the BOQ. In the end the material brought in causes a considerable amount of residual material, and changes in material specifications or changes in the image are also one of the causes. The project produced the most waste or waste material from iron cutting, then the multiplex material from the formwork work. The work had the highest percentage of construction waste contributed to the project.

2. How to minimize construction waste that occurs in the One Galaxy Apartment Development project in Surabaya by monitoring the implementation of the work that produces the most waste so that the waste can be controlled according to what is 
needed and for waste that has already happened will be offered to other projects at other projects need these materials if there is no one who needs the material waste will be sold to construction waste disposal or it can also be under to the central workshop to be managed by the relevant agencies and as for material that can be exchanged with suppliers to be replaced by other materials to minimize the material not used .

\section{REFERENCE}

Bossink dan Brouwers, 1996, Construction waste: quantification and source evaluation, Univ. of Twente, Enschede, The Netherlands.

Wulfram, I.E., Biemo, W.S., M. Abduh, Surjamanto. 2012. Study of Building Material Reuse in Sustainable Construction Concepts in Indonesia. Journal, Bandung Institute of Technology.

Tchobanoglous, 1995, Integrated solid waste management: Engineering principles and management Issues. New York : McGraw-Hill, Inc.

Greenwood, Rubina, (2004). Construction Waste Minimisation Good Practice Guide. Welsh School Arch

Gavian dan Bernold, (1994). craven et al. , 1994, Minimizing waste on construction project sites, Australia

Johnston dan Mincks, (1992), Waste management for the construction manager.

ICF Incorporated, 1995). Construction and Demolition Waste Landfill. Prepared for EPA Office of Solid Waste.

Peng, Chun-li, Domenic E. Scorpio, Charles Kibert. (1995). Strategis for Succesful Contruction and Demolition Waste Recycling Operations. Journal of Construction Engineerinig Management.

Branz, (2002). Easy Guide to Reducing Construction Waste. Australia.

Muhammad Fatih, Yusuf Latief, Suratman (2012) The Effect of Building Environmental Management Aspects on Green Building Construction Costs compared to Conventional Building, University of Indonesia.

Sugiyono, (2004). Qualitative research methods, and R\&D, Alphabet Jakarta.

Sitepu1, D.P., Syahrizal., Dewi, R.A. 2011. Analysis of Construction Material Remaining Using the Fault Tree Analysis Method. Journal, University of North Sumatra.

Diana, W.H., Farida, R., Cahyono, B.N. 2013. Analysis of Construction Material Remnant in the Surabaya State University Professional Teacher Education Building Project. Journal, Sepuluh November Institute of Technology Surabaya.

Endy Marlina, (2008) Commercial Building Design Guide, Yogyakarta.

Putri and Utomo, 2012, Assessment of Green Building Criteria in the ITS Civil Engineering Building. Journal of Engineering POMITS. Vol.1.No.1

Post The President (2013), Development of Green Building in Indonesia. Muhammad Fatih, 2012, The Effect of Building Environmental Management Aspects on Green Building Construction Costs Compared to Conventional Buildings. FISIP, University of Indonesia.

T.A. Fikriyah, P.Ary.2016 "Green Building Concept in Spazio Office Building, Surabaya". Faculty of Engineering, Universitas Brawijaya, 1-8. 